\title{
TOURISM DEVELOPMENT IN YUANTONG ANCIENT TOWN
}

\author{
Andreea LINCU* \\ Ph.D. candidate, University of Oradea, Department of Geography, Tourism and Territorial Planning, \\ University St., 410087, Oradea, Romania, e-mail: lincu_andreea@yahoo.com
}

Citation: Lincu, A. (2019). Tourism Development in Yuantong Ancient Town. Analele Universităţii din Oradea, Seria Geografie, 29(2), 194-211. https://doi.org/10.30892/auog.292119-822

\begin{abstract}
The aim of this article was to find out if the tourism development in Yuantong town is satisfactory for both the locals and visiting tourists. The survey method was used and two different questionnaires were drafted and then filled by the two aimed groups. One questionnaire was for locals and one for visitors. The end results show that both groups are pleased so far with the development of the town and while not everyone shared the same views and opinions, the majority were satisfied with how the tourism industry is developing and growing in Yuantong ancient town, China.
\end{abstract}

Key words: survey, toursim development, ancient town, local economy

$$
* \quad * \quad * \quad * \quad * \quad *
$$

\section{INTRODUCTION}

This survey took place during a period of two days in Yuantong Ancient City (figure 1 and 2) and it involved a series of questions split in two questionnaires. By definition a survey is: "the collection of information from a sample of individuals through their responses to questions" (Check and Schutt, 2012). One questionnaire had questions designed for the local community and the other questions for the visiting tourists. A total of 58 questionnaires were filled by locals and another 59 by visitors. This method of research was used because there is not enough local data made public to show the effects tourism is having in Yuantong Ancient Town.

Many town houses and heritage buildings along with other monuments were restored and infrastructure was improved in order to make this location a touristic spot (figure 1 and 2).

The respondents were randomly selected, there was no criteria based on which they were approached for both questionnaires. There is no notable difference between all those approached that agreed or did not agree to participate except for the fact maybe that more older persons, who looked to have an age past 65 , refused than younger persons did. But not many were approached because the majority of visitors and workers in Yuantong were younger. A lot of the visitors were accompanied by at least 2 more persons, and some groups were larger than 5 . In many cases, each group had at least one child or teenager in it. This suggests that this town is preferred by families. The results of the questionnaires also showed that because all respondents said there are accompanied by family or friends, where those that were visiting with family were considerably

\footnotetext{
${ }^{*}$ Corresponding Author
} 
more. Overall the local community said that Yuantong is a good place to live, even for young people and there are not many problems faced by the community. More than $60 \%$ said that they are currently pleased with the way Yuantong was developed as a touristic attraction and around $20 \%$ were undecided. But more than $50 \%$ consider that there are not enough tourists visiting their town. Only $25 \%$ of the respondents said that their family income relies on tourism. More than $50 \%$ consider the government involvement satisfactory and a lot more agree that the buildings are well preserved and restored. Over $70 \%$ of respondents from the local community agreed or strongly agreed that tourism contributes to the local community by creating jobs, increasing spending in the local businesses, supports local shops, museums, festival, events and heritage sites, helps maintain local tradition and identity and attracts investments into the area. The main problems the locals are facing are the lack of jobs or economic opportunity according to $25 \%$ of respondents and low wages mentioned by $15 \%$. The lack of cultural amenities was also an issue for $15 \%$ and poor educational opportunities for $10 \% .25 \%$ of respondents said that none of the mentioned are a problem.

The visitors on the other hand were asked about how pleased they were with their visit and more than $70 \%$ said that the trip to Yuantong met their expectations. Almost all respondents were visiting for just 1 day, half day or 2-3 hours, were accompanied by either family or friends and $90 \%$ of them were from the Sichuan province and arrived there by car. More than $60 \%$ were workers and closet to $20 \%$ students. Almost everyone was visiting Yuantong for rest and relaxation. More than $90 \%$ said this was their main visiting reason. More than $50 \%$ of respondents declared to have spent between 50 to 100RMB per person per day on food, shopping and other activities. All of this data shows that Yuantong Ancient Town is a destination for families that live in the nearby cities in the Sichuan province that arrive by private care to spend a relaxing day and then return back home later that same day. When asked to evaluate the overall attractiveness of the town, the quality of restaurants and cafes, and the local attractions, almost all statements received more than $70 \%$ ratings ranging from good to excellent. In general, the tourists seemed very relaxed and happy enjoying their day together with their families and friends and were pleased about Yuantong and its restaurants and local attractions.

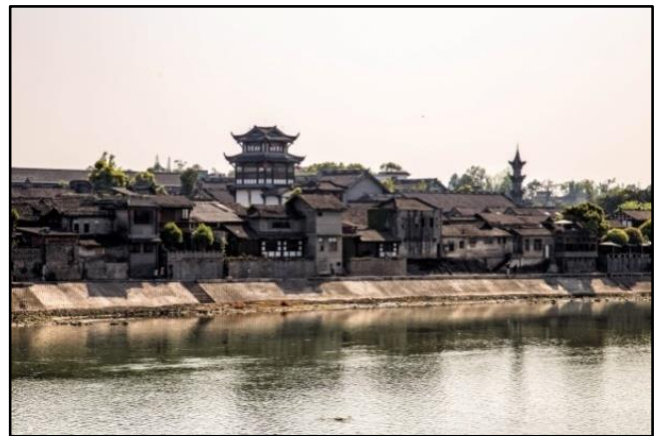

Figure 1. Yuantong Ancient Town riverbed side

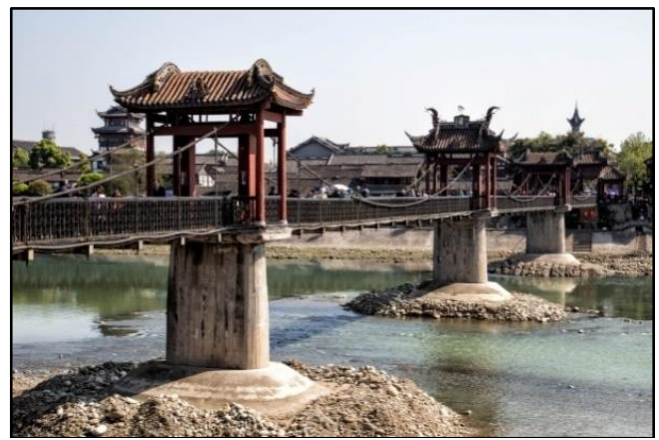

Figure 2. Yuantong Ancient Town-Huijiang Bridge

\section{BACKGROUND AND OBJECTIVES}

This research could be necessary in order to determine if the development and restoration of the ancient town was and is satisfactory for the local community.

The tourism economic impact plays a major role because of the many tourists that spend money in Yuantong town or other similar locations and affect the income of the local businesses be it directly or indirectly (Research Resolutions \& Consulting Ltd, 2007).

It is also important to know if the influx of tourists visiting has led to an increase in the quality of life of the local community or if it has turned things for the worse. This is important to ensure the long-term success of this smaller attraction that lies on the outskirts of the city of Chengdu. There are multiple small ancient towns in proximity of the city and Yuantong must 
compete with all of them to attract tourists. Jiezi ancient town must be in particular taken into consideration because it is very close to Yuantong and it is a much bigger town with many more shops, hotels and restaurants. So Jiezi could be the more obvious destination to travel to. These ancient towns are very good weekend destinations for the people that live in, or close to, the city of Chengdu or other smaller, but still developed cities that are close. So, it is also important to determine through research such as this one if the tourists that visit Yuantong have a good experience and enjoy their stay in this ancient town. Any issue found should be addressed in the future in order to ensure the long-term survivability of this ancient location as a touristic destination.

The first objective of this study was to get a basic understanding of the impact tourism is having on the local community. To understand if they are pleased with the fact that Yuantong has become a touristic attraction, to know how they profit from this fact and see if they think and feel about how tourism contributes to life in their community. The impact tourism is having on smaller communities is a concern raised in various papers (Allen et al., 1988; Mahony and Van Zyl, 2002; Leon, 2007; Gabriel Brida et al., 2011; Herman et al., 2017, 2018a; Ilie et al., 2017).

The second objective was to receive feedback from visiting tourists and understand their preferences and why they chose to spend their day in Yuantong. It is necessary to understand their needs so that future development can also take these into consideration to ensure the long-term prosperity of this town as a touristic attraction.

\section{METHODOLOGY}

This survey was performed to study the tourism development of a certain area in a similar fashion other surveys were conducted for much the same reasons in different towns and areas (Tyrrell et al., 1984; Sheldon and Var, 1984; Rønningen, 2010; Johnson, 1994; Chhabra et al., 2003; Ritchie and Inkari, 2006; Miller, 2003).

Various research methods using surveys can be found throughout many different studies and papers (Ritchie, 1988; Lankford, 1994; Sinclair, 1998; Snaith and Haley, 1999; Simmons, 1994; Ilieș et al., 2015; Bar et al., 2016; Herman et al., 2018b; Wendt et al., 2019).

In order to determine how beneficial, the tourism development of Yuantong ancient town currently is, from the point of view of the locals and visitors, the method used to collect data was face-to-face interview survey using printed questionnaires. "Face-to-face interviews involve the researcher approaching respondents personally, either in the street or by calling at people's homes. The researcher then asks the respondent a series of questions and notes their responses." (Kelley et al., 2003). The main reason this method was select is because there is not enough available public data to draw conclusions regarding this research. The survey took place mostly on a Sunday when visitors were engaged and the following Monday when a portion of the questionnaires for local were filled.

"A questionnaire is the main means of collecting quantitative primary data. A questionnaire enables quantitative data to be collected in a standardized way so that the data are internally consistent and coherent for analysis" (Roopa and Rani, 2012).

There were two types of questionnaires used, one for locals and the other for visitors. Both questionnaires were printed on A4 paper format, front and back, and feature a horizontal design. Questions were thought of to be easy and fast to reply to and mainly focused on the satisfaction of the local community and visitors regarding the touristic development of the ancient town. It was important to find out if visitors could access the location quick and easy and if they found everything they wanted and needed once there. Information about if all their needed were suited was most important. For the local community a different set of questions were designed from which it could be later concluded if the development of the ancient town as a touristic destination has improved their quality of life, if they are satisfied with the current situation, the amount they earn, the number of tourists visiting the ancient town and if their earnings are related to touristic activities. 
The survey was completed in 2 days and a total of 117 questionnaires were filled. 59 questionnaires by locals and 58 by visitors. The survey took place inside the ancient town area. Because this is more of a weekend destination, Sunday was selected to ensure there are enough visitor to approach for this survey and the rest of the remaining questionnaires intended for locals were filled in on Monday. There were no criteria on which the tourist respondents were selected other than the fact that they had to be visitors who were not living in Yuantong.

The questionnaires for locals were mostly filled by owners and workers of small businesses such as shops, restaurants and other services. These criteria were used to see the impact tourism had on this sector and on the local economy.

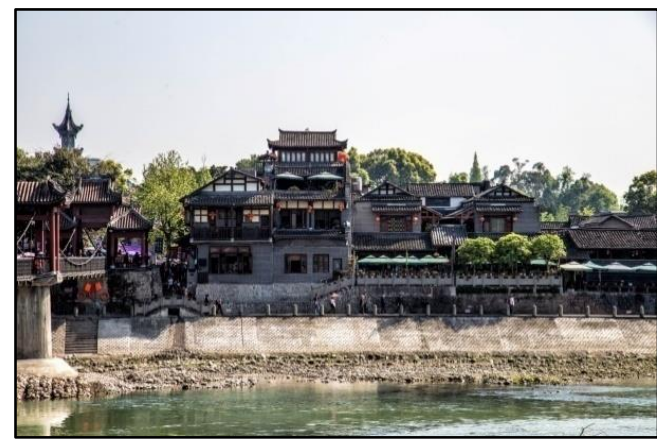

Figure 3. Yuantong Ancient Town riverbed side

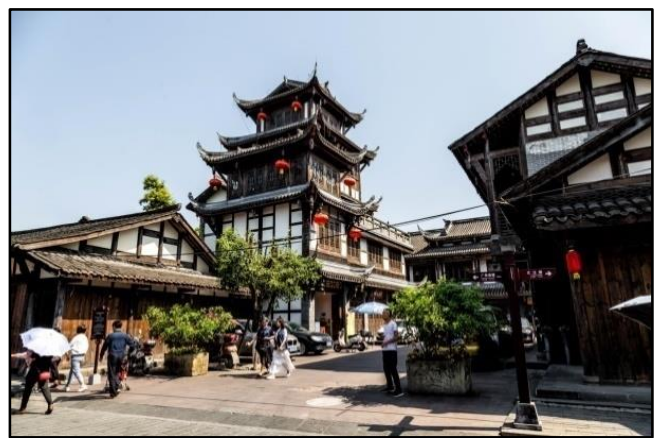

Figure 4. Yuantong Ancient Town centre

There were 58 questionnaires filled by visitors. There was no identification process used. People were approached on the street, in restaurants and shops and were asked if they are visitors and wish to participate in a quick survey. This was the approach used for each respondent and if the answer was no, no other attempts were made to try and convince this person. Only one attempt was made every time. Around $70 \%$ to $80 \%$ of the persons approached agreed to take part in the survey and most were very glad to do it. There is no notable difference in gender or other demographic criteria observed between the respondents and those who did not wish to fill in the questionnaire. It was observed that some of those who declined were over the age of 55, but this cannot be determined for sure. Most of the persons approached were in groups larger than 3 persons which indicates that this is more of a family destination. A large number of respondents of the visitor survey had kids with them. This questionnaire for visitors proved to be good because it took almost everyone only 3 to 4 minutes to complete. It included question such as why are they visiting the town, if the location met their expectation and asked them to rate the quality of different locations they have experienced, restaurants they ate in and the services that were provided on site.

The other 59 questionnaires were specifically designed for and filled by people from the local community. The identification process required these persons to live, work or own a business in Yuantong ancient town. The response rate was much higher for this questionnaire. Around $90 \%$ of the people approached were happy to respond and many were quite glad they could be a part of this research. All were approached in their shop or street stall where they were working. There is also no notable demographic difference regarding the $10 \%$ that did not wish to be a part of the survey. A few had to refuse because they were busy serving customers. Also, it was noticed that more females responded to this questionnaire because a lot of the business owners and employees of the places we went into or street stalls we stopped at were of this gender. This questionnaire proved to take longer to fill and each respondent spent at least 10 minutes answering the survey questions. The people from the local community were asked to answer questions such as if their family income relies on the local tourism, if there are enough tourists visiting and to rate how tourism affects their lives having multiples answers to give a grade to from 1 to 5 . 


\section{RESULTS}

\section{RESULTS TARGETING THE LOCAL COMMUNITY}

The local community was very responsive when asked if they would like to participate in a survey regarding tourism development in Yuantong Ancient Town. Around 90\% of those who were asked were very receptive and gladly agreed to fill in the questionnaire right away. It was found that $90 \%$ of the respondents are residents but only 20 declared that their family's income relies on the local tourism, that means that $35 \%$ of the locals that replied profit and depend on the number of tourists visiting their town. When asked if this number is large enough, if there are enough tourists visiting Yuantong Ancient Town, 39 replied with no and 20 with yes (figure 5).

\section{Q1. Do you live in Yuantong Ancient Town?}

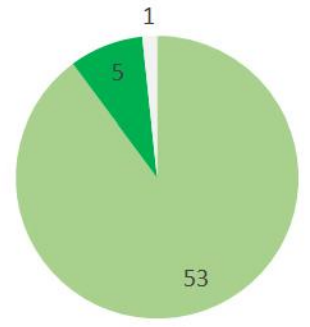

Yes No No answer

\section{Q2. Does your family income rely on the local tourism in Yuantong Ancient Town?}

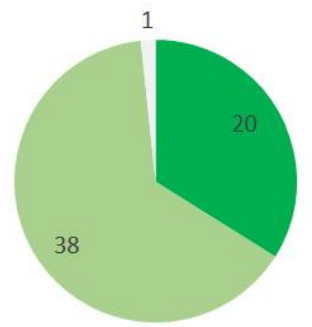

Y Yes No No answer

\section{Q3. Do you think that are enough tourists visiting Yuantong Ancient Town?}

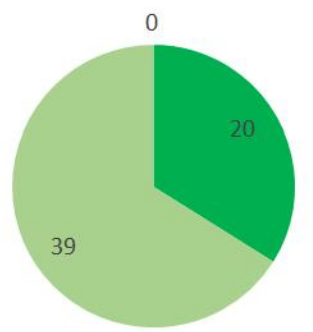

Yes No No answer

Figure 5. Question 1,2 and 3 from the questionnaire targeting the local community

Question 4 on the questionnaire had a series of statements that the respondents had to select how much they agree or disagree with each sentence. The overall response was a positive one and more than $50 \%$ agreed or strongly agreed with most of the positive statements. More $20 \%$ remained undecided for most of these affirmations. $75 \%$ of the people agreed with more of them selecting that they strongly agree that Yuantong is a good place to live. For the statements: There is not much for your people here and that the local community faces a lot of problems living here, results were fairly similar with around $50 \%$ of the respondents saying that they disagree or strongly disagree with these statements, with another $25 \%$ saying that they are undecided. There were a few persons that chose not to answer, which left only $22 \%$ agreeing out of which only 4 strongly agreed.

Asked if the quality of life has improved since the tourism development, more than $50 \%$ agreed or strongly agreed, where $25 \%$ remained undecided. But almost $60 \%$ remained positive and agreed and strongly agreed that future prospects for the area are good. $25 \%$ remained undecided and very few did not agree. More than $50 \%$ also agree that the tourism industry has good relationships with the local community but it should also put more back into the local community. $20 \%$ remained undecided (figure 6).

The most positive responses regarding this set of statements were received when asked if they agree or disagree that tourism is important for the long-term prosperity of the local community and that old heritage buildings are well preserved and properly restored. Around $80 \%$ agreed or strongly agreed and only a few did not agree. The rest, up to $15 \%$ remained undecided.

The fact that the government involvement was satisfactory for the development of the area was also agreed upon by more than $50 \%$ of the respondents and $25 \%$ remained undecided. Only $20 \%$ did not agree with this statement. 


\section{Q 4. How do you feel about the tourism development in Yuantong Town? Please indicate your agreement/disagreement with the following statements.}

Yuantong Town is a good place to live.

There is not much for young people here.

The local community faces a lot of problems living here.

The quality of life here has improved since the tourism development.

Future prospect for this area is good.

The tourism industry should put more back into the local community.

The tourism industry has good relations with the local community.

Tourism is important for the long-term prosperity of the local community.

The government involvement was satisfactory for the development of the area.

Old heritage buildings are well preserved and properly restored.

The tourist who come here cause damage to the environment.

Strongly disagree $\square$ Disagree Agree
- Strongly agree
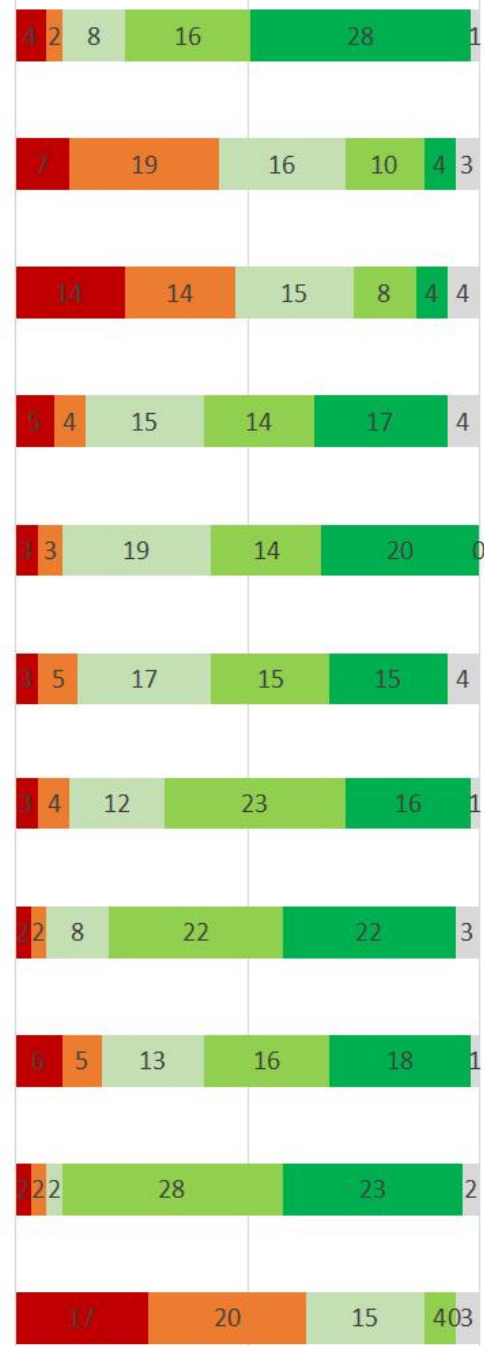

0\% Undecided $50 \%$

$100 \%$

No answer

Figure 6. Question 4 from the questionnaire targeting the local community

The last in this series of affirmations was that the tourists who come to Yuantong town cause damage to the environment and more than $60 \%$ did not agree or strongly disagreed with this and $25 \%$ remained undecided. Less than $10 \%$ agreed (figure 6 ). 


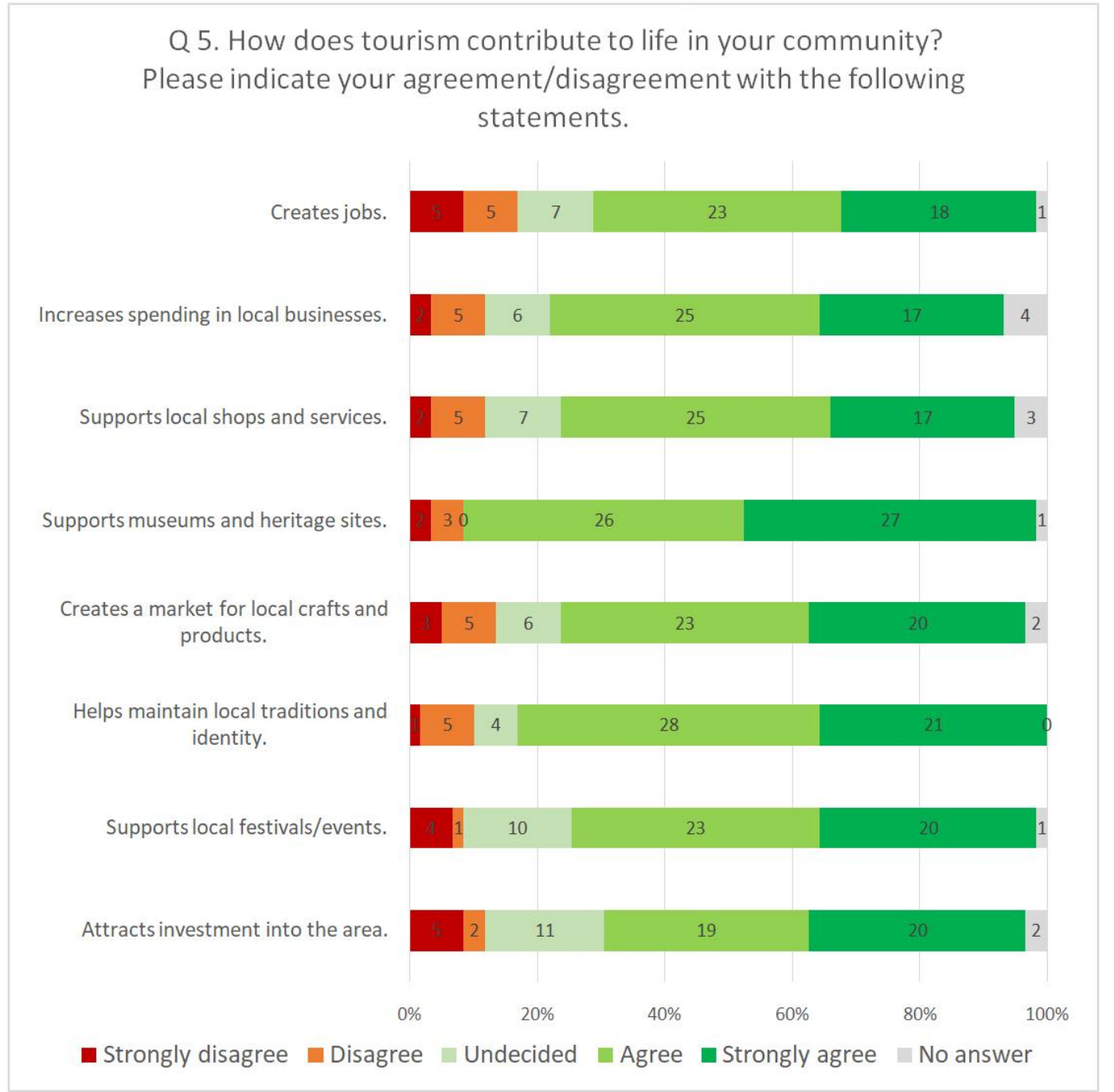

Figure 7. Question 5 from the questionnaire targeting the local community

The following question (figure 7) was how does tourism contribute to life in the local community and again a set of statements were given for the respondents to agree or disagree with. In this case, everyone agreed a lot more with all of the positive affirmations listed. More than $70 \%$ agreed or strongly agreed with the facts that tourism contributes by creating jobs, increases spending in local businesses, supports local shops and services, supports museums and heritage sites, creates a market for local crafts and products, helps maintain local traditions and identity, supports local festivals and events and attracts investment in the area. Around $10 \%$ or more remained undecided and for most questions a little over 10\% did not agree or strongly disagreed. Only very few chose not to give an answer for this question. The fact that tourism contributes by supporting museums and heritage sites was the only statement that did not have any undecided respondents and less than $10 \%$ disagreed. The rest of $90 \%$ agreed or strongly agreed, and just 1 person did not answer (figure 7).

When asked if the problems listed (figure 8) are present in their community, the results were mixed. $25 \%$ selected that the lack of jobs and economic opportunity is a problem. More than 
$10 \%$ said that low wages are a problem and the following statements were also selected by more than $10 \%$ each: Lack of cultural amenities and poor educational opportunities. A little over $20 \%$ of the respondents stated that none of the mentioned affirmations are a problem and $20 \%$ said that there are other issues in their community. None suggested any of these other problems. 4 chose not to answer (figure 8).

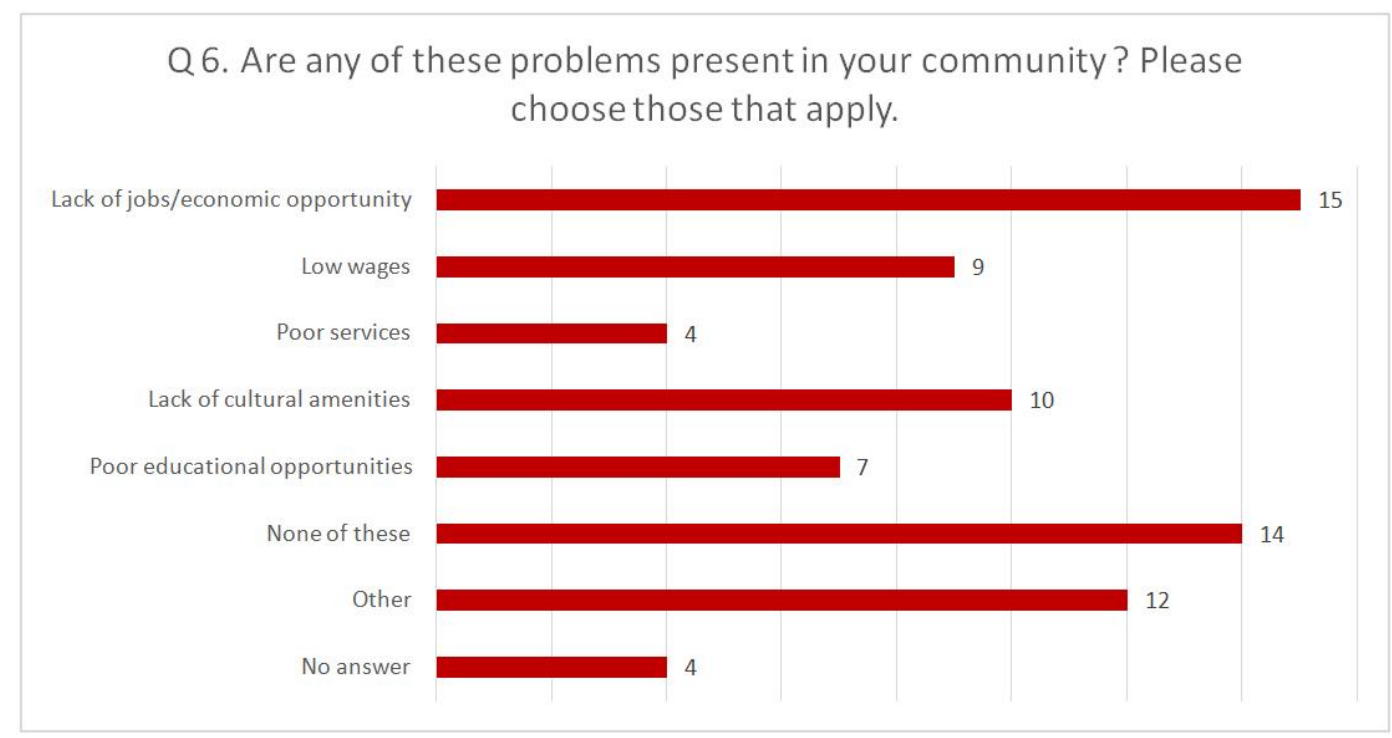

Figure 8. Question 6 from the questionnaire targeting the local community

Q 7. How old are you?

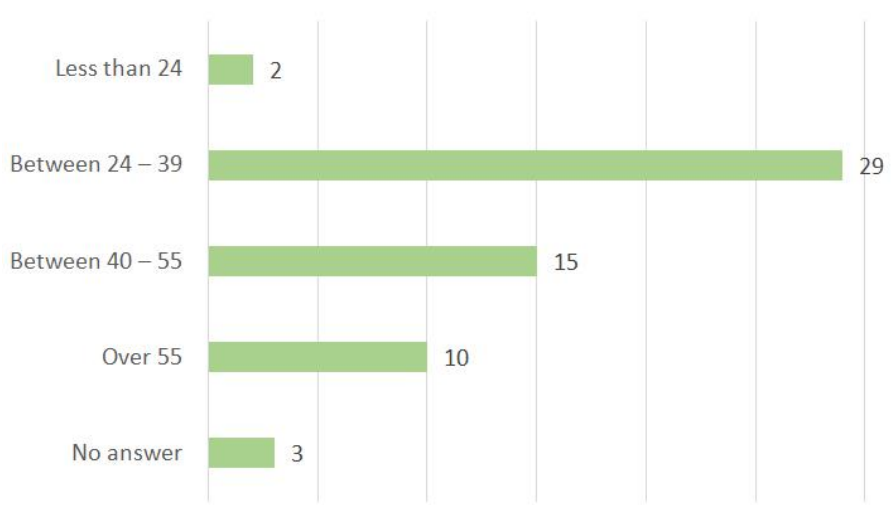

Q 8. Are you?

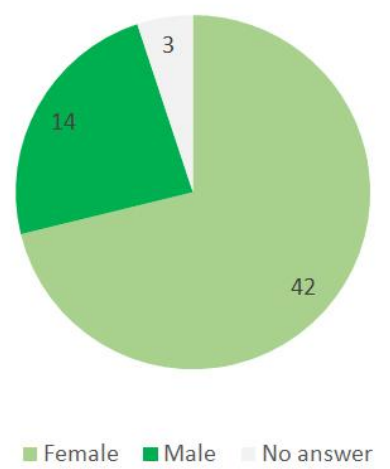

Figure 9. Question 7 and 8 from the questionnaire targeting the local community

Out of the 58 respondents that filled in the questionnaire 42 where females and only 14 were males. 3 did not answer. Out of these, 29 declared to have an age between 24 to 29, 15 between 40 and 55, 10 people over 55 and only 2 had an age of less than 24.3 chose not to answer (figure 9).

\section{SURVEY TARGETING THE VISITORS}

There was a total of 59 respondents that answered the questions of the questionnaire intended for visitors. Out of these, 33 had an age between 24 and 39, 7 between 40 and 55, 14 were under 24 years old and only 3 were over 55 years old. $90 \%$ said that they are from the 
Sichuan province, 2 from Zhe Jiang, 1 from Guang Dong, 1 from Shan Dong and 1 did not answer (figure 10 and 11).

\section{Q 1. How old are you?}

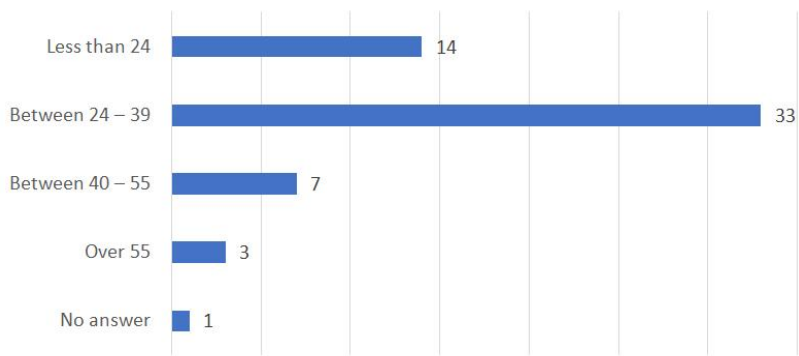

Figure 10. Question 1 from the questionnaire targeting the visitors

\section{Q 2. Which province are you from?}

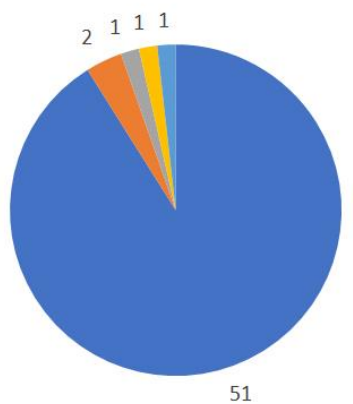

Q3. What is your current status?

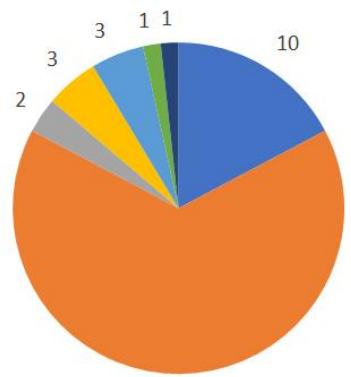

38

Figure 11. Question 2 and 3 from the questionnaire targeting the visitors

When asked about their status, $65 \%$ declared that they are workers, $15 \%$ said that they are students and the remaining $20 \%$ said they were unemployed, retired, business owners or other. 1 did not answer this question (figure 11).

The top main reason, chosen by more than $90 \%$ of the respondents, for visiting Yuantong Ancient Town was rest and relaxation. 3 were visiting or meeting with relatives or friends. 4 said they were visiting for culture and festival and another 3 for walking and nature (figure 12).

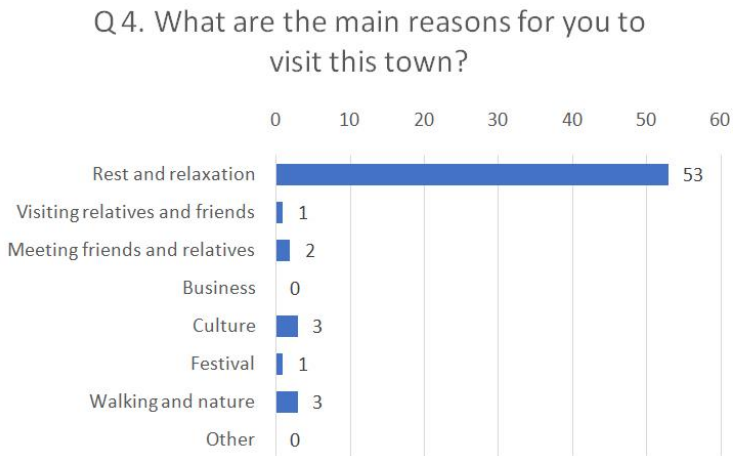

Figure 12. Question 4 from the questionnaire targeting the visitors 
When asked about how did they found out about Yuantong town, 24 said that they already knew of it, 23 chose the internet option and 13 said they know of it from friends and relatives. Only 1 chose the media option and 1 chose travel agency. None reported to have known about the town from books or guides (figure 13).

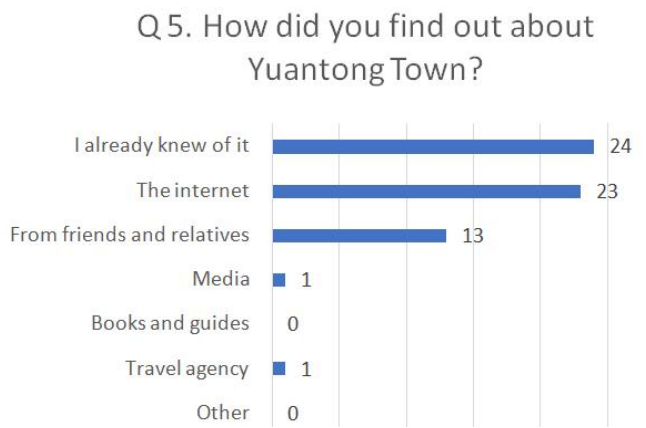

Figure 13. Question 5 from the questionnaire targeting the visitors

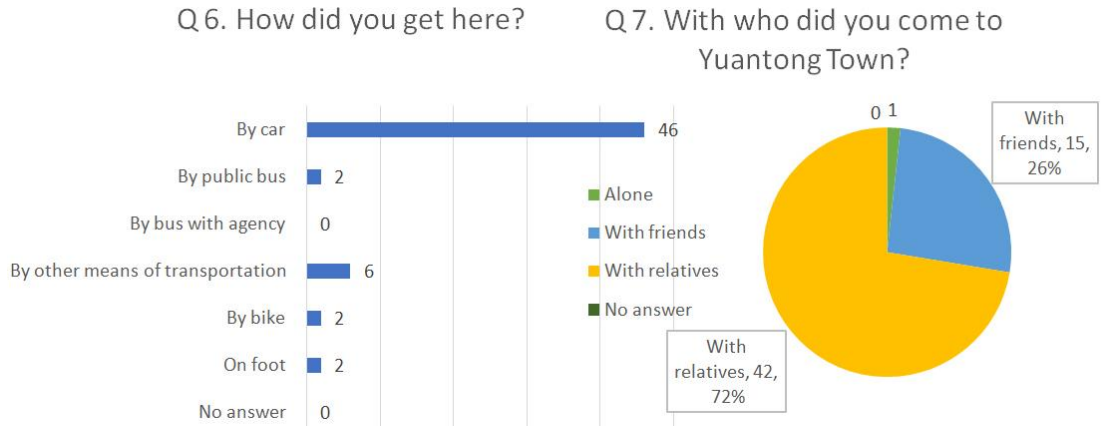

Figure 14. Question 6 and 7 from the questionnaire targeting the visitors

$72 \%$ of the respondents declared that they are visiting the town accompanied by relatives and family and $26 \%$ with friends. Only one person said to be visiting alone. Out of these, 46 , which is more than $75 \%$ said that they arrived there by car. 2 chose the public bus option, 2 arrived by bike, 2 on foot and 6 said that they arrived by other means other than the ones listed (figure 14). $70 \%$ declared that they are visiting for a full day and $12 \%$ selected the half day option. 6 were there for only 2 or 3 hours. Only 1 person said that the visit length is 1 to 2 days. 4 chose not to answer (figure 15).

Q 8. How many days are you staying in Yuantong Ancient Town?

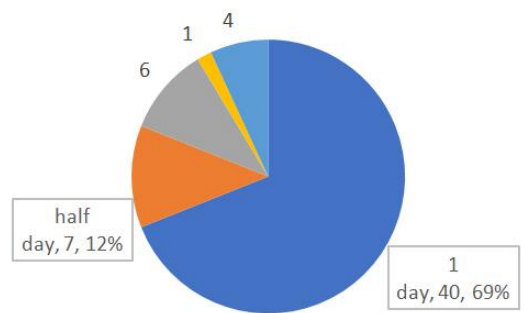

Q9. Is this your first visit to Yuantong Ancient Town?

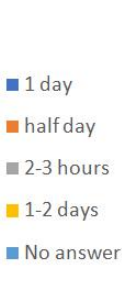

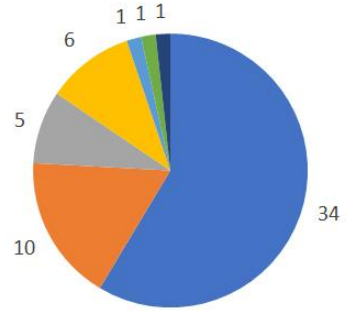

- Yes.

No.

No. One time

No. Two times

No. Many time

- No. Ten times

- No answer

Figure 15. Question 8 and 9 from the questionnaire targeting the visitors 
Asked if this was their first visit to Yuantong Ancient Town, almost $60 \%$ replied with a yes. $15 \%$ said no. 1 person had already been there one more time, 6 had previously been there 2 times before, 1 many times, 1 ten times and 1 did not answer (figure 15).

Regarding the annual net income of the respondents, the results vary. Out of the 59, 17 said that they earn between 60.000 to $100.000 \mathrm{RMB}, 12$ between 30.000 and $60.000 \mathrm{RMB}, 14$ under 30.000RMB and 7 said that they earn more than 100.000RMB. 8 persons chose not to answer this question. The next question was regarding now much money they have spent during their visit in Yuantong Town per person, per day on accommodation. More than $30 \%$ said to have spent less than 100RMB and 30\% more than 100 to 300RMB. 20 did not answer this question (figure 16).
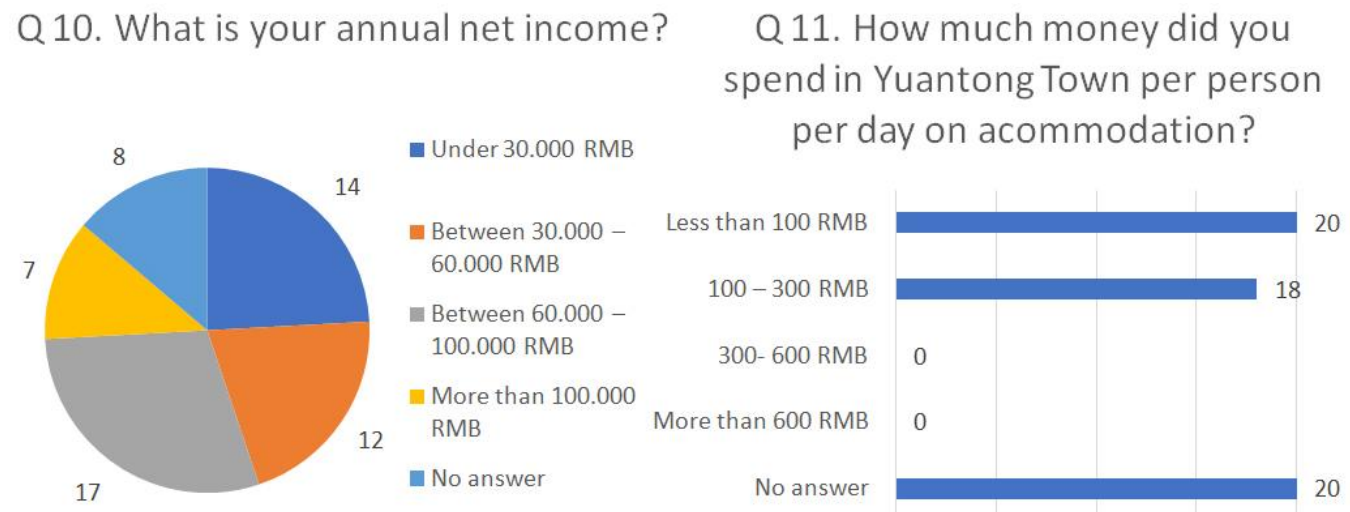

Figure 16. Question 10 and 11 from the questionnaire targeting the visitors

As a follow up, they were also asked how much money they had spent per person, per day on food, shopping and other activities. More than 50\% reported to a spending of 50 to 100RMB, 14 spent 100 to $200 \mathrm{RMB}, 5$ more than 200RMB and 7 said that they have spent less than 50RMB (figure 17).
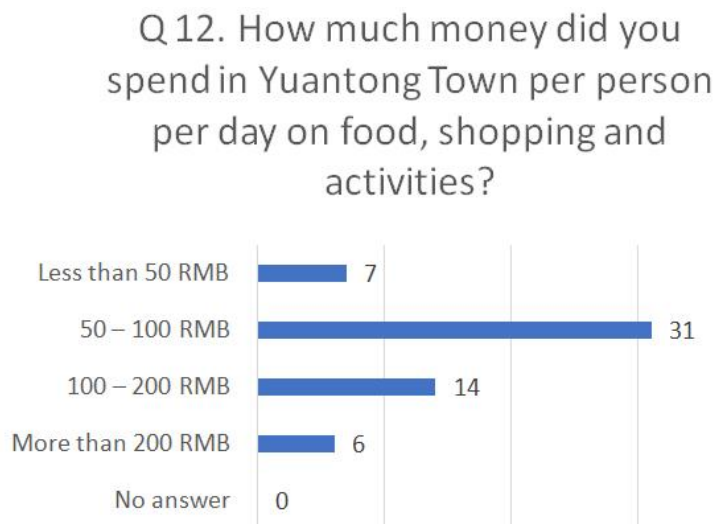

Figure 17. Question 12 from the questionnaire targeting the visitors

The following questions were to ask the respondents to evaluate with reviews ranging from poor to excellent the quality of accommodation, restaurants and cafes, the overall aspect and accessibility of the town and different touristic attractions that can be found on location. Regarding the quality of their accommodation, more than 50\% replied with answers ranging from good to excellent, $10 \%$ chose the poor option and more than $30 \%$ did not answer. The quality of 
restaurants and cafes along with the overall aspect of Yuantong town received positive feedback where most chose the good or very good option and a few, under $10 \%$, chose excellent. 10 did not state their opinion about the quality of restaurants and cafes and a little over $10 \%$ chose the average option in both situations. Only one person rated the quality of restaurants and cafes as poor. The overall aspect of the town had the most positive feedback where $85 \%$ replied with good, very good and a few with excellent. Concerning the accessibility of Yuantong town by public transportation, more than $50 \%$ declared that it is good, very good and $10 \%$ chose the excellent option. $15 \%$ said that it is average from which one said that it is poor. $25 \%$ chose not to give a rating (figure 18).

When asked to evaluate the attractiveness of the enumerated local attractions which were: Catholic Church, Liu's Manor, Trading Hall, Pagoda and Xiejiang River, close to 70\% rated each of these attractions as good, very good and excellent. Out of the $70 \%$, close to $25 \%$ said that the attractiveness was good, around $20 \%$ said very good and close to $15 \%$ said rated with excellent. More than $10 \%$ rated the attractions with average and less than 5\% reviewed their attractiveness as poor. More than $10 \%$ overall chose not to rate these local heritage buildings, monuments and river (figure 19).

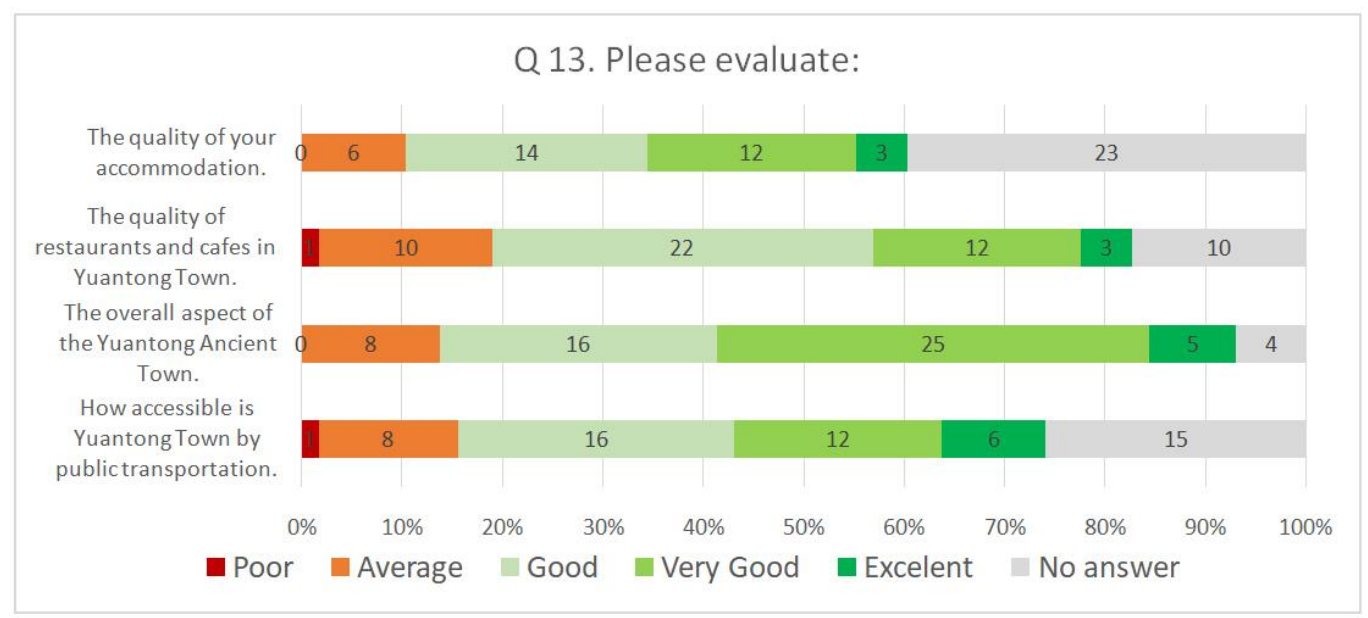

Figure 18. Question 13 from the questionnaire targeting the visitors

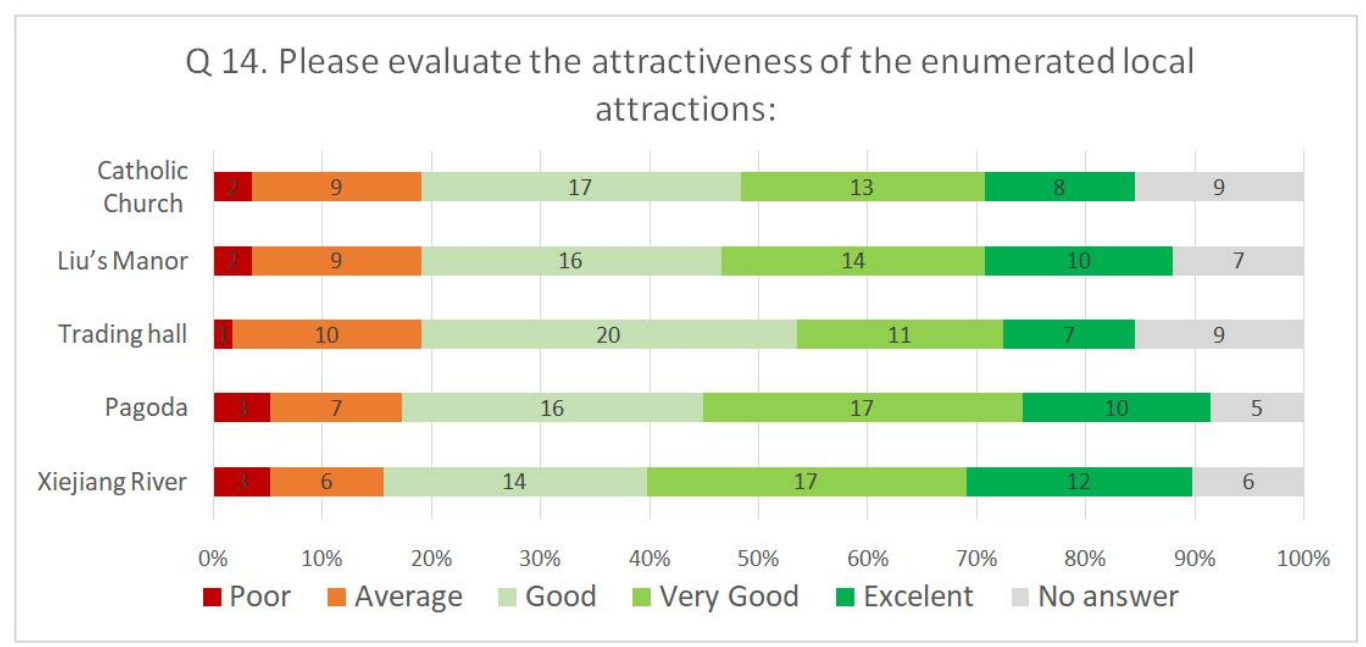

Figure 19. Question 14 from the questionnaire targeting the visitors 


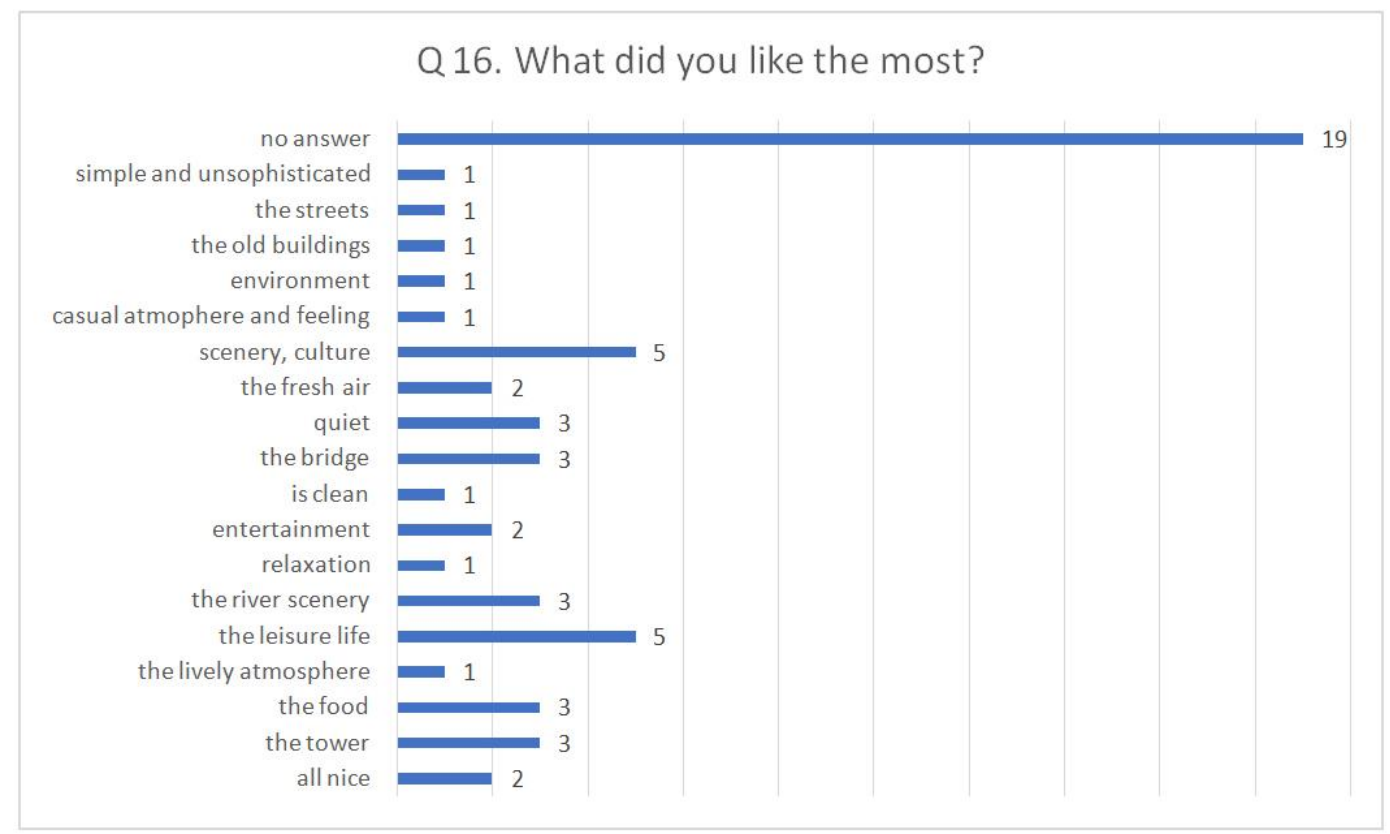

Figure 20. Question 16 from the questionnaire targeting the visitors

The last questions were about what did they like or dislike the most in Yuantong Ancient Town. Over $30 \%$ did not say what they liked most and among those who did, the most popular answers were culture, scenery and leisure life. The next most popular answers were the fact that is is quiet, the bridge, the food and the tower. Other things like the streets, old buildings, environment, casual atmosphere, clean, entertainment and fresh air were also mentioned. For the what did they dislike the most, more than $70 \%$ of respondents did not answer. Only 2 persons mentioned that they did not like the fact that the town was too small and another 2 mentioned that they did not like the weather. Inconvenient parking, tea too expensive, a little untidy, toilets, too commercial, inconvenient transport, some attractions being closed and the fact that the tea houses built on the side of the river are obscuring the original natural look were also each mentioned once.

Overall, $79 \%$ or respondents said that their trip to Yuantong met their expectations and only a little over $10 \%$ said no. less than $10 \%$ did not answer this question.

\section{Q 15. Did your trip to Yuantong Ancient Town meet your expectations?}

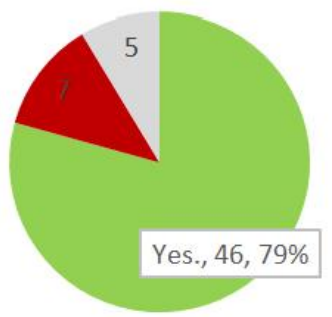

Yes.

No.

No answer

Figure 21. Question 15 from the questionnaire targeting the visitors 


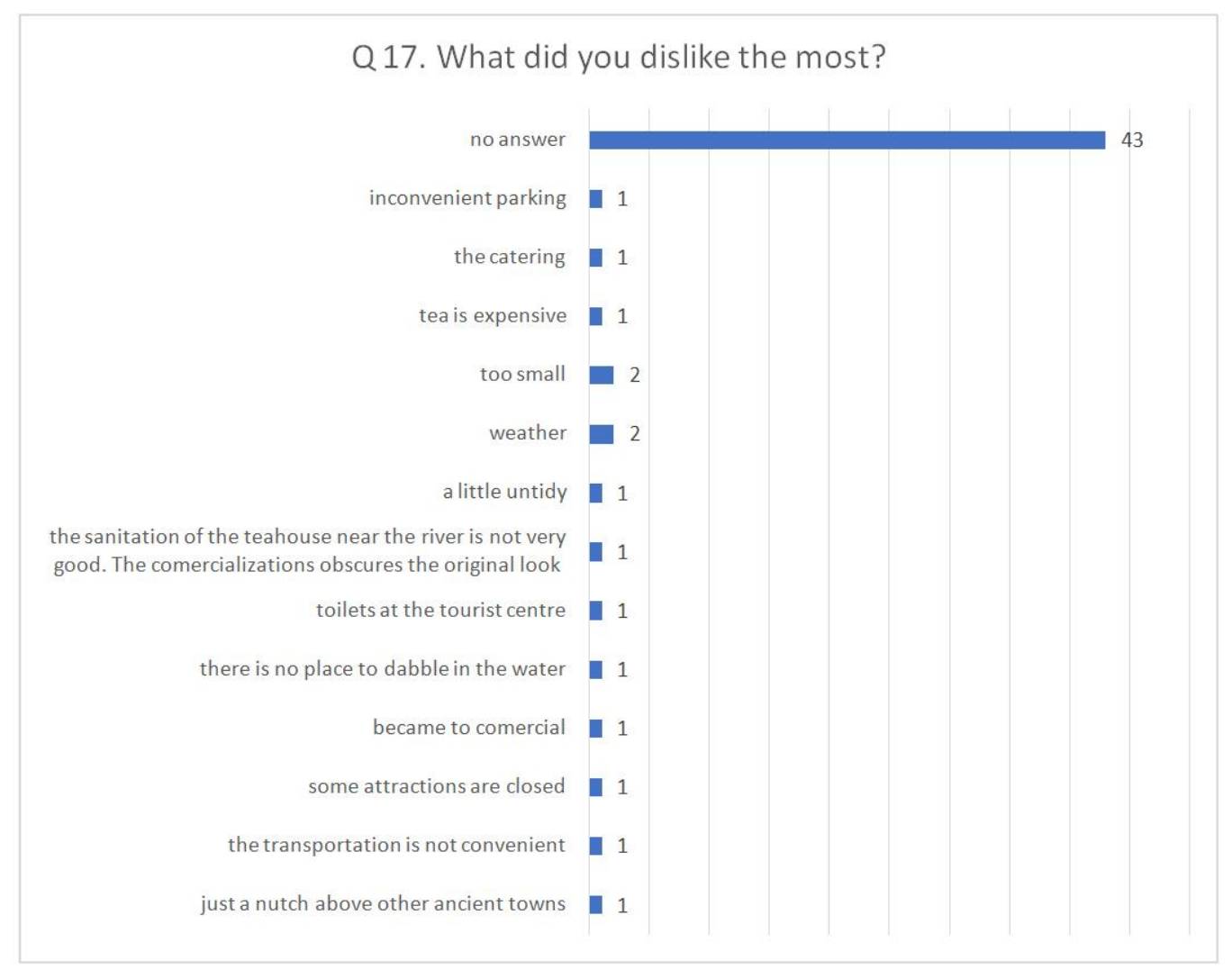

Figure 22. Question 17 from the questionnaire targeting the visitors

\section{CONCLUSION}

\section{Survey Targeting the Local Community}

In conclusion the local community was much more receptive and curious about the survey. Most of the people who participated are residents of the town. But only a little over $30 \%$ of them said that their family income relies on local tourism. So more than $60 \%$ of the locals are still not dependent on the number of tourists visiting. Also, a little more than $30 \%$ considered that there are not enough tourists visiting Yuantong and the rest of more than $60 \%$ said that there are enough. Most of those who rely on tourism fortheir family's income have also stated that there are not enough tourists visiting the ancient town.

Overall the respondents consider Yuantong Town a good place to live and also around 50\% of them disagreed or strongly disagreed with the fact that there is not much for young people there and that the local community faces a lot of problems living in this town. Another 25\% remained undecided and only around $20 \%$ agreed with these statements. In the view of the local community, Yuantong still has a lot to offer, even for the younger generations and many considered that they do not face a lot of problems living there.

Regarding the quality of life, the answers suggest that it has improved a lot since it has become a touristic spot. Future prospects are also very promising for the local community and more than half agreed to this. Some remained undecided and only a few did not agree. But people also consider that the tourism industry has good relations with the local community and that it should also put more back into it. So, the people have high expectation regarding the tourism development, the long-term development and how much they profit from it. More than $70 \%$ agreed or strongly agreed that tourism is important for the long-term prosperity of the local community 


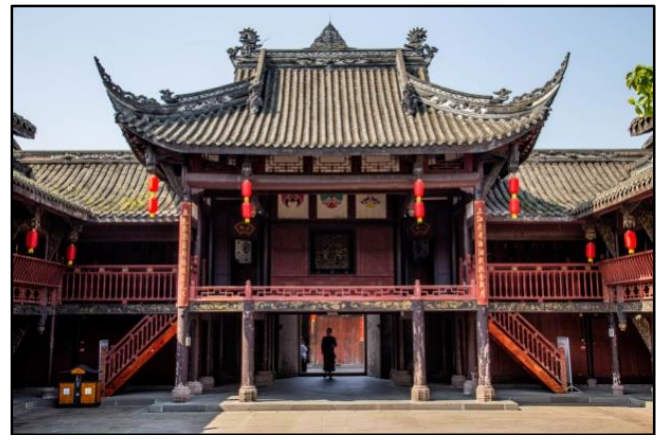

Figure 24. Yuantong ancient town - trading hall

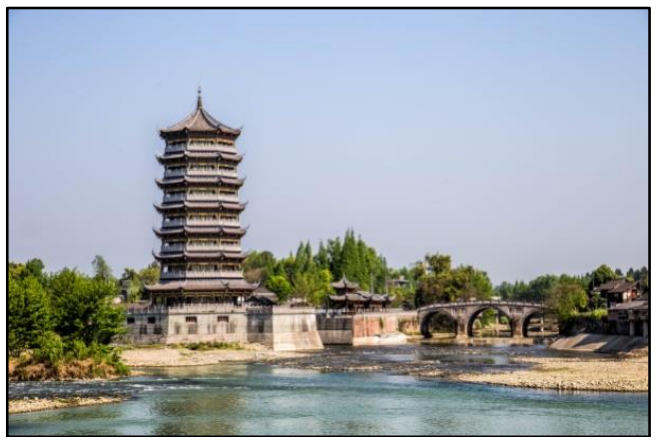

Figure 25. Yuantong ancient town - Pagoda

Many of the houses were rebuilt and restored in Yuantong town, along with the monuments, old heritage buildings and the bridge as part of the plant to develop tourism and make this town a destination worth visiting. And most of this was done with a lot of assistance from the government. More than $50 \%$ of respondents agreed that the government involvement in this matter was satisfactory, where $90 \%$ said that the old heritage buildings are well preserved and properly restored. This could suggest that the government, in some of the respondent's opinion, could do more for their community other than restoring the ancient town buildings and monuments. But this could not be the case since regarding this matter only $20 \%$ said that the involvement was not satisfactory and another $20 \%$ remained undecided. The local community is also satisfied with the visitor's behavior and most consider that the tourists that visit their town don't cause damage to the environment. Only less than $10 \%$ agreed that they do.

Tourism seems to become more and more important for a town such as Yuantong. Most respondents agreed that tourism contributes by supporting and increasing the local economy. Facts such as tourism helps create jobs, increases spending in local businesses, supports local shops, services, museum, heritage sites, festival and events and last but not least, attracts investment into the area, are very important. More than $70 \%$ of respondents agree to this and even if only a little over $30 \%$ declared that their family income relies on local tourism, a lot more agree how important tourism actually is for the entire local community.

According to 15 persons, there is a lack of jobs and economic opportunity in Yuantong. 9 others suggested that the wages are low. Some said that their community has poor services and poor educational opportunities and another 10 people indicated that there is a lack of cultural amenities. 14 people reported problems other than the ones listed but did not mention what. These responses show that there are still some issues in an area such as this one and even if the recent development has brought in a lot of tourists, not all problems have been fixed as much as the local people are concerned. The lack of jobs or jobs with low wages are the main concern for the locals where the lack of cultural amenities and education come in second. Only $25 \%$ of the respondents said that none of the listed issues are a problem. This leaves more than $70 \%$ that worry about certain issues that their community is facing.

Almost $70 \%$ of the respondents for the local community survey were females. This was in no case intentional. This just shows that there are more women working and interacting with the tourists in the shops and restaurants in the Yuantong Ancient Town than man do. It was observed that there were more men working in the kitchens of the restaurants in the central square but these were not available for the survey as they were busy with their jobs. Among all of the local people who were approached and also replied, only 2 persons were under the age of 24 and most were young adults having ages ranging from 24 to 45 , and these were around half of those who were part of the survey, where the rest where middle-aged women and men with ages starting from 45 to 65 . 


\section{Survey Targeting the Tourists}

People that were visiting and agreed to be a part of the survey were mostly under the age of 40. This was not intentional. More than $50 \%$ were young adults and $25 \%$ were adolescents. It was observed that the tourists arriving into town were mostly young adults accompanied by children or teenagers and some older people. Almost all respondents were from the Sichuan provice and were workers and some students. Rest and relaxation were the main reason for their visit. This shows that Yuantong is a destination mostly for working people who are looking for a good place to relax and spend the weekend with their family and friends. Most of the people that were approached were in groups of at least 3 people and some in groups larger than 5 . More than $70 \%$ did declare that they are visiting accompanied by relatives and $25 \%$ by friends.

Yuantong seems to be a good destination for the weekend. This results from the fact that almost all of the respondents declared that they are only visiting for a few hours, half a day or one day. $80 \%$ of the visitors arrived by car. All of this data results show that Yuantong is a destination that people from the nearby cities use a relaxation spot for a single day. Almost everyone said to have arrived there by car which can be an effective mean of transportation to access such location and return back home later that same day.

More than half declared that it is their first time visiting this town. A few said that they have been there one time before, others two times and 2 more than 10 times.

The annual net income of the 59 respondents varies a lot. The results were equally split between people who earned less than 30.000RMB, to people who earned between 30.000 to 100,000RMB and those that had a net income larger than 100.000RMB. But the amount of money people spent was quite similar for everyone, per person per day. More than $60 \%$ declared that they have spent less than 100RMB and another 25\% said to have spent between 100 to 200RMB. Only $10 \%$ spent more than 200RMB. People were also asked about how much they have spent on accommodation but it is unclear if they actually spent the night in a hotel or not because this was not asked. And since most declared to be visiting for just 1 day, the following data could not apply. More than 30\% said to have spent less than 100RMB per person per day for accommodation and another 30\% said 100 to 300RMB. 20 did not answer and this suggests that they did not spend the night in Yuantong. Again, when asked to evaluate the quality of their accommodation, 23 persons, more than $30 \%$ did not answer.

The respondents were also asked to evaluate the quality of restaurants and cafes, overall aspect of the town and how accessible it is by public transportation. The results were positive and most people evaluated the above mentioned as good, very good and a few even rated with an excellent. $25 \%$ did not answer when asked to evaluate how accessible is Yuantong town by public transportation. This could be due to the fact that according to the previous question that asked people to say how they arrived there, most than $80 \%$ said that they arrived by car. So, it would seem that very few actually used public transportation to get there, 2 persons to be more precise compared to the 46 who arrived by car.

Yuantong is destination that people knew of or found out about from the internet or friends and relatives. This suggests that the town is best promoted online and by word of mouth.

The local attractions received good reviews. More than $70 \%$ considered these to be Good, Very Good or Excellent even. Only around 10\% rated with average and even fewer with poor. The attractions are: Catholic Church, Liu's Manor, Trading Hall (figure 24), Pagoda (figure 25) and Xeijiang River (figure 3 and 5) along with its old bridge (figure 4). These attractions were restored and during the period of the survey, Liu's Manor and the Trading Hall were open for visits. There were no activities happening on the river such as boat rides.

It resulted from the question that was asking the respondents what did they like the most that, overall, people were most satisfied with the atmosphere of the town including the streets and buildings, scenery and culture, environment, leisure life, the river and a few mentioned the food and river. 30\% did not answer this question. Even more chose not to reply to what they disliked the most. Out of 59 persons, 43 gave no answer. Out of those that did, a few things 
were mentioned like the parking, expensive tea, weather, no place to dabble in the water, too commercial, too small, toilets at the tourist center and the fact that transportation is not convenient. But most of these dislikes received just a single mention each. So, overall there were not many who had any complaints. Question 15 results are also good proof that most visitors in Yuantong town have they expectation met. Almost $80 \%$ declared this and only a little over $10 \%$ said otherwise.

Yuantong is a good weekend destination for those who live in the province of Sichuan, China who wish to trade the noise and agglomeration of the big cities with the quiet and relaxation a small ancient town like Yuantong can offer. Most of the local community considers that tourism is important for the long-term prosperity of their town and are saying that the quality of life has improved since more visitors started to show. And most of the visitors are happy with what Yuantong has to offer them and their families.

\section{REFERENCES}

Allen, L. R., Long, P. T., Perdue, R. R., \& Kieselbach, S. (1988). The impact of tourism development on residents' perceptions of community life. Journal of travel research, 27(1), 16-21.

Bar, R., Tătar, C.F., \& Herman, G.V. (2016). Satisfaction degree rating of tourist services in Buziaş spa, Timiş County, Romania. GeoJournal of Tourism and Geosites, 18 (2), 212-223.

Check, J., \& Schutt, R. K. (2011). Research methods in education. Sage Publications.

Chhabra, D., Healy, R., \& Sills, E. (2003). Staged authenticity and heritage tourism. Annals of tourism research, 30(3), 702-719.

Gabriel Brida, J., Osti, L., \& Faccioli, M. (2011). Residents' perception and attitudes towards tourism impacts: A case study of the small rural community of Folgaria (Trentino-Italy). Benchmarking: an international journal, 18(3), 359-385.

Herman, G. V., Deac, A. L., Ciobotaru, A.-M., Andronache, I. C., Loghin, V., \& Ilie, A. M. (2017). The role of tourism in local economy development. Bihor County Case Study. Urbanism Architecture Constructions, 8(3), 265-274.

Herman, G. V., Peptenatu, D., Grama, V., \& Pintilii, R. D. (2018a). Tourism and Local Development. Study Case: Băile Felix-Băile 1 Mai Tourism System, Bihor County, Romania. Analele Universitatii din Oradea. Seria Geografie, 28(1), 131-137.

Herman, G. V., Tătar, C. F., \& Puşcaş, B. D. (2018b). Assessing the importance of the Jewish urban cultural heritage in Oradea, Bihor County, Romania. Forum Geografic, 17(2), 151-158.

Ilie A. M., Herman G. V., Ciobotaru A. M., Grecu A., Radu R. A., Visan M. C., \& Giurgia M. (2017), The role of tourism in structural dynamics of the economic profile of Sighisoara city. Urbanism Architecture Constructions, 8(4), 377-386.

Ilieș, D. C., Buhaș, R., Ilieș, A., Morar, C., \& Herman, G. (2015). Nymphaea Lotus Var. Thermalis (Pârâul Pețea Nature Reserve), Brand Near Extinction of the Băile Felix-Băile 1 Mai (Romania) Spa Tourism System. GeoJournal of Tourism \& Geosites, 15(1), 107-117.

Johnson, J. D., Snepenger, D. J., \& Akins S. (1994). Residents' perceptions of tourism development. Annals of Tourism Research, 21 (3), 629-642.

Kelley, K., Clark, B., Brown, V., \& Sitzia, J. (2003). Good practice in the conduct and reporting of survey research. International Journal for Quality in health care, 15(3), 261-266.

Lankford, S. V. (1994). Attitudes and perceptions toward tourism and rural regional development. Journal of travel research, 32(3), 35-43.

León, Y. M. (2007). The impact of tourism on rural livelihoods in the Dominican Republic's coastal areas. The Journal of Development Studies, 43(2), 340-359.

Mahony, K., \& Van Zyl, J. (2002). The impacts of tourism investment on rural communities: three case studies in South Africa. Development Southern Africa, 19(1), 83-103.

Miller, G. A. (2003). Consumerism in sustainable tourism: A survey of UK consumers. Journal of Sustainable Tourism, $11(1), 17-39$

Research Resolutions \& Consulting LTD. (2007). Guidelines: Survey Procedures for Tourism Economic Impact Assessments of Gated, Permanent Attractions,Federal-Provincial-Territorial Culture/Heritage and Tourism Initiative and Tourism British Columbia, pp. 8.

Ritchie, B. W., \& Inkari, M. (2006). Host community attitudes toward tourism and cultural tourism development: the case of the Lewes District, Southern England. International journal of tourism research, 8(1), 27-44.

Ritchie, J. B. (1988). Consensus policy formulation in tourism: Measuring resident views via survey research. Tourism management, 9(3), 199-212.

Rønningen, M. (2010). Innovation in the Norwegian rural tourism industry: Results from a Norwegian survey. The Open Social Science Journal, 3, 15-29.

Roopa, S., \& Rani, M. S. (2012). Questionnaire designing for a survey. Journal of Indian Orthodontic Society, 
46(4_suppl1), 273-277.

Sheldon, P. J., \& Var, T. (1984). Resident attitudes to tourism in North Wales. Tourism management, 5(1), 40-47.

Simmons, D. G. (1994). Community participation in tourism planning. Tourism management, 15(2), 98-108.

Sinclair, M. T. (1998). Tourism and economic development: A survey. The journal of development studies, 34(5), 1-51.

Snaith, T., \& Haley, A. (1999). Residents' opinions of tourism development in the historic city of York, England. Tourism management, 20(5), 595-603.

Tyrrell, T. J., \& Spaulding, L. A. (1984). A survey of attitudes toward tourism growth in Rhode Island. Hospitality Education and Research Journal, 8(2), 22-33.

Wendt, J., Buhaş, R., \& Herman, G. V. (2019). Experience of the Baile-Felix Tourist System (Romania) For the Protection and Promotion of the Grey Seal as a Brend on the Hel Peninsular (Poland). Baltic Region/Baltijskij Region, 11(1), $109-116$

Submitted:

July 05,2019
Revised:

November 27, 2019
Accepted and published online

December 20, 2019 